Article

\title{
Enhancing Output Power of Textured Silicon Solar Cells by Embedding Indium Plasmonic Nanoparticles in Layers within Antireflective Coating
}

\author{
Wen-Jeng Ho ${ }^{1, * \mathbb{D}}$, Jheng-Jie Liu ${ }^{1}$, Yun-Chieh Yang ${ }^{1}$ and Chun-Hung Ho ${ }^{2}$ \\ 1 Department of Electro-Optical Engineering, National Taipei University of Technology, Taipei 10608, Taiwan; \\ jjliu@mail.ntut.edu.tw (J.-J.L.); t105658043@ntut.edu.tw (Y.-C.Y.) \\ 2 Realtek Semiconductor Corp., No. 2, Innovation Road II, Hsinchu Science Park, Hsinchu 300, Taiwan; \\ cunhonho@gmail.com \\ * Correspondence: wjho@ntut.edu.tw or wjho@mail.ntut.edu.tw; Tel.: +886-2-2771-2171 (ext. 4639)
}

Received: 15 November 2018; Accepted: 30 November 2018; Published: 4 December 2018

\begin{abstract}
In this study, we sought to enhance the output power and conversion efficiency of textured silicon solar cells by layering two-dimensional indium nanoparticles (In NPs) within a double-layer $\left(\mathrm{SiN}_{x} / \mathrm{SiO}_{2}\right)$ antireflective coating (ARC) to induce plasmonic forward scattering. The plasmonic effects were characterized using Raman scattering, absorbance spectra, optical reflectance, and external quantum efficiency. We compared the optical and electrical performance of cells with and without single layers and double layers of In NPs. The conversion efficiency of the cell with a double layer of In NPs $(16.97 \%)$ was higher than that of the cell with a single layer of In NPs $(16.61 \%)$ and greatly exceeded that of the cell without In NPs $(16.16 \%)$. We also conducted a comprehensive study on the light-trapping performance of the textured silicon solar cells with and without layers of In NPs within the double layer of ARC at angles from $0^{\circ}$ to $75^{\circ}$. The total electrical output power of cells under air mass (AM) $1.5 \mathrm{G}$ illumination was calculated. The application of a double layer of In NPs enabled an impressive 53.42\% improvement in electrical output power (compared to the cell without NPs) thanks to the effects of plasmonic forward scattering.
\end{abstract}

Keywords: indium nanoparticles (In NPs); textured silicon solar cells; antireflective coating (ARC); plasmonic forward scattering

\section{Introduction}

Most commercial solar cells are fabricated using a silicon-based wafer ranging in thickness from 150 to 200 micrometers. Light trapping in crystalline silicon solar cells is generally achieved using a pyramidal structure with an antireflective coating on the surface. This combination allows for the multiple reflection and scattering of incident light within the solar cell [1-8]. Metallic nanoparticles (NPs) [9-12] of silver (Ag NPs) [13-16], gold (Au NPs) [17-20], and aluminum (Al NPs) [21-24] have been applied to the front and/or rear-side surfaces of silicon solar cells to increase light trapping and enhance photovoltaic performance. Metallic NPs can be resonantly coupled with incident light, thereby allowing a portion of the light to be scattered into the absorber layer. Far-field forward light scattering from metallic NPs and a near-field enhanced localized field in the vicinity of the metallic NPs have been shown to boost the conversion efficiency of photovoltaic devices $[9,25]$. Researchers have investigated the use of various metallic materials in these devices. They have also controlled the dimensions, shapes, spacing, and surrounding dielectric environments of the NPs to enhance resonant plasmonic scattering $[9,11]$. In addition, a dielectric-based $\left(\mathrm{TiO}_{2}\right)$ photonic structure using colloidal-lithographed processing was also proposed for light trapping in thin film photovoltaics [26]. 
Indium nanoparticles (In NPs) exhibit plasmonic resonance in the ultraviolet range (below $280 \mathrm{~nm}$ ) and broadband plasmonic light scattering from visible and near-infrared wavelengths [27-29], which makes them capable of boosting the conversion efficiency of photovoltaic devices. However, there has been relatively little research on the embedding of In NP sheets within a double-layer antireflective coating (DL-ARC) to enhance the photovoltaic performance of textured silicon solar cells [30-33].

In this study, we examined the plasmonic light scattering of In NPs of various dimensions, which were embedded in a coating of $\mathrm{SiO}_{2}$ with a DL-ARC structure $\left(\mathrm{SiN}_{x} / \mathrm{SiO}_{2}\right)$ for use in textured silicon solar cells. The plasmonic effects of samples with single and double layers of In NPs were characterized according to Raman scattering, absorbance, optical reflectance, and external quantum efficiency (EQE). We also measured the EQE and photovoltaic current-voltage (I-V) as a function of incident angle using cells with and without In NPs. We then calculated the total output electrical power of cells under AM 1.5 G illumination. The application of a double layer of In NPs enabled an impressive 53.42\% improvement in output electrical power (compared to the cell without NPs) thanks to the effects of plasmonic forward scattering. The novelty of this study includes (a) the enhancement in output power and conversion efficiency of textured silicon solar cells by layering two-dimensional In NPs within a DL-ARC, and (b) a comprehensive study on the light-trapping performance of the textured silicon solar cells with and without layers of In NPs within the DL-ARC at angles from $0^{\circ}$ to $75^{\circ}$, both of which are issues beyond the scope of previous studies [30-33].

\section{Experiments}

\subsection{Characterization of Plasmonic Effects from Indium Nanoparticle Layers Embedded in $\mathrm{SiO}_{2}$ Coating}

Quartz substrates were used as a test template to characterize the plasmonic effects of indium nanoparticles in the UV-VIS band, due to their high transparency (low absorption) at UV-band wavelengths. Figure 1 presents a schematic diagram of (a) an $\mathrm{SiO}_{2}$ coating (90 nm) deposited on a quartz substrate, (b) a single layer of In NPs embedded in a $\mathrm{SiO}_{2}$ coating $(90 \mathrm{~nm})$, and (c) a double layer of In NPs embedded in a $\mathrm{SiO}_{2}$ coating $(90 \mathrm{~nm})$. The $\mathrm{SiO}_{2}$ layer and In $\mathrm{NPs}$ were deposited using electron-beam (e-beam) evaporation. The In NPs were formed by depositing indium films at thicknesses of $3.8,5$, and $7 \mathrm{~nm}$ directly on the quartz substrate or the $\mathrm{SiO}_{2}$ coating and then applying rapid thermal annealing (RTA) at $200{ }^{\circ} \mathrm{C}$ under $\mathrm{H}_{2}$. The average surface coverage and average diameter of the In NPs were as follows: $3.8 \mathrm{~nm}(36.75 \%$ and $20.13 \mathrm{~nm}), 5 \mathrm{~nm}(41.83 \%$ and $25.03 \mathrm{~nm})$, and $7 \mathrm{~nm}$ $(46.46 \%$ and $32.14 \mathrm{~nm})$. These results were calculated using image-J software from corresponding SEM images. Sample (b) was fabricated by applying a layer of In NPs on the quartz substrate and then capping it with a 90-nm coating of $\mathrm{SiO}_{2}$. Sample (c) was fabricated by applying an initial layer of In NPs on the quartz substrate and covering it with a 20-nm spacer layer of $\mathrm{SiO}_{2}$ before applying a second layer of In NPs over the spacer layer and capping it with an additional 70-nm coating of $\mathrm{SiO}_{2}$.

(a)

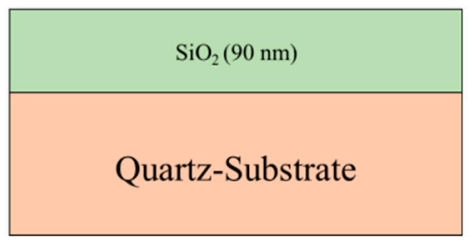

(b)

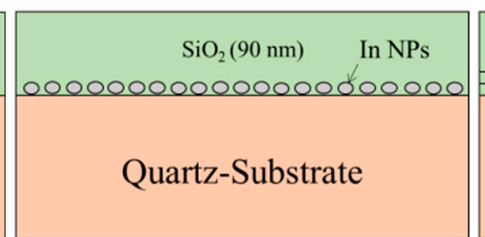

(c)

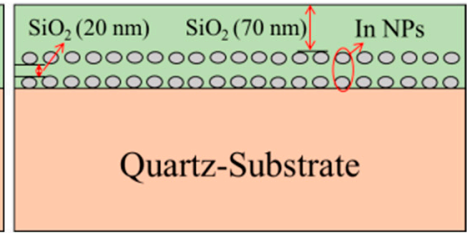

Figure 1. Schematic diagrams of proposed samples: (a) $\mathrm{SiO}_{2}$ coating (90 nm) deposited on quartz substrate; (b) single layer of In NPs embedded in $\mathrm{SiO}_{2}$ coating $(90 \mathrm{~nm})$ on quartz substrate; and (c) double layer of In NPs embedded in $\mathrm{SiO}_{2}$ coating $(90 \mathrm{~nm}$ ).

The plasmonic effects of the In NPs (single and double layers) were examined using Raman scattering and absorbance measurements. Raman scattering spectra were collected using a Raman spectrometer (UniRAM, UniNanoTech Co., Yongin-si, Giheung-gu, Korea) with a 532-nm laser 
(approximately $3 \mathrm{~mW}$ ), with the signal accumulated over a period of $30 \mathrm{~s}$. The observed shifts in the Raman peaks and variations in Raman signal intensity revealed that the plasmonic effects depend on the number of NP layers and the dimensions of the In NPs they comprise. Absorbance spectra were collected using a miniature spectrometer (USB4000-VIS-NIR, Ocean Optics, Inc., Largo, FL, USA) with a deuterium tungsten light source $(200-2000 \mathrm{~nm})$ and reflective integrating sphere (diameter of $5 \mathrm{~cm}$ ). The obtained absorbance spectrum revealed the intensity of surface plasmon resonance (SPR) and the SPR absorption band induced by In NPs. Both measurements were also obtained from the sample without In NPs (as a control) to confirm the plasmonic effects of In NPs layered within the $\mathrm{SiO}_{2}$ coating.

\subsection{Fabrication and Characterization of Plasmonic Textured Silicon Solar Cells}

Boron-doped (P-type) crystalline silicon wafers with a (100) orientation and resistivity of $10 \Omega$-cm were cut to a thickness of $150 \mu \mathrm{m}$ to use them as a base material for textured silicon solar cells. Following standard Radio Corporation of America (RCA) cleaning, the saw-damaged surface of the silicon wafers was removed by dipping them in a solution of $\mathrm{H}_{2} \mathrm{O} / \mathrm{KOH}$ (Potassium). The surface of the wafer was then etched by dipping it in a solution of $\mathrm{H}_{2} \mathrm{O} / \mathrm{KOH} / \mathrm{IPA}$ (Isopropanol) at $80{ }^{\circ} \mathrm{C}$ for $20 \mathrm{~min}$ to create a surface texture in the form of randomly-arranged pyramidal structures. The textured wafers then underwent RCA cleaning prior to the application of an $n^{+}-S i$ emitter layer with a sheet resistance of approximately $80 \Omega$ /sq using a $\mathrm{POCl}_{3}$ diffusion process in a tube diffusion chamber at $850{ }^{\circ} \mathrm{C}$ over a period of $3 \mathrm{~min}$. The wafer was then cut into samples of $10 \mathrm{~mm}^{2}$. The oxide layer that formed on the surface of the samples was removed using hydrogen fluoride (HF) solution prior to the deposition of an $\mathrm{Al}$ film with a depth of $2 \mu \mathrm{m}$ on the rear surface using e-beam evaporation. The as-deposited wafer was then annealed at $450{ }^{\circ} \mathrm{C}$ for $5 \mathrm{~min}$ to form a back electrode with a good ohmic contact to the p-silicon. Plasma-enhanced chemical vapor deposition (PECVD) was used to deposit a 70-nm silicon nitride film on the front surface as an antireflective coating. Finally, top contact grid-electrodes were formed from a Ti film $(20 \mathrm{~nm})$ and Al film $(10,000 \mathrm{~nm})$ using photolithographic etching, e-beam evaporation, and lift-off processes. The resulting textured silicon solar cells (as shown in Figure 2a) underwent characterization in terms of optical and electrical performance for use as a reference by which to evaluate the performance of the plasmonic solar cells.

Figure 2 presents schematic diagrams showing the silicon solar cells tested in this study: 2(a) presents the bare reference silicon solar cell; 2(b) shows the solar cell with an $\mathrm{SiO}_{2}$ coating $(90 \mathrm{~nm})$ without In NPs (DL-ARC; $\mathrm{SiN}_{x} / \mathrm{SiO}_{2}$ ); 2 (c) shows the solar cell with an $\mathrm{SiO}_{2}$ coating $(90 \mathrm{~nm}$ ) embedded with a single layer of In NPs; $2(\mathrm{~d})$ shows the solar cell with an $\mathrm{SiO}_{2}$ coating $(90 \mathrm{~nm})$ embedded with a double layer of In NPs (same dimensions in each layer) separated by a 20-nm $\mathrm{SiO}_{2}$ spacer layer. Note that the total thickness of the $\mathrm{SiO}_{2}$ coatings and embedded layers was maintained at $90 \mathrm{~nm}$.

As described in Section 2.1, the layers of In NPs were fabricated by depositing indium film using e-beam evaporation with thicknesses of $3.8 \mathrm{~nm}, 5 \mathrm{~nm}$, and $7 \mathrm{~nm}$, followed by annealing in an RTA chamber at $200{ }^{\circ} \mathrm{C}$ under $\mathrm{H}_{2}$ for $30 \mathrm{~min}$. A scanning electron microscope (SEM; Hitachi S-4700, Hitachi High-Tech Fielding Corporation, Tokyo, Japan) was used to characterize the sample surfaces and cross-sections. Optical reflectance (Lambda 35, PerkinElmer, Inc., Waltham, MA, USA) and external quantum efficiency (EQE; Enli Technology Co., Ltd., Kaohsiung, Taiwan) measurements were used to assess the plasmonic effects of the In NPs layers embedded within the $\mathrm{SiO}_{2}$ coating. The photovoltaic performance of the textured silicon solar cells (with and without In NPs layers) was assessed in terms of photovoltaic current-voltage (I-V) under AM 1.5 G illumination. The solar simulator (XES-151S, San-Ei Electric Co., Ltd., Osaka, Japan) was calibrated using a National Renewable Energy Laboratory (NREL)-certified crystalline silicon reference (PVM-894, PV Measurements Inc., Boulder, CO, USA) prior to measurement. 


\section{(a)}

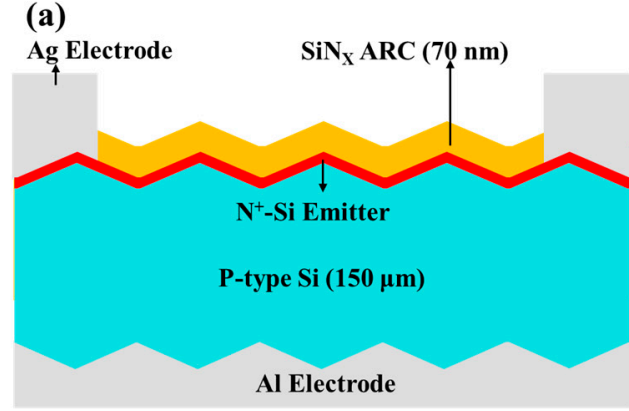

(c)

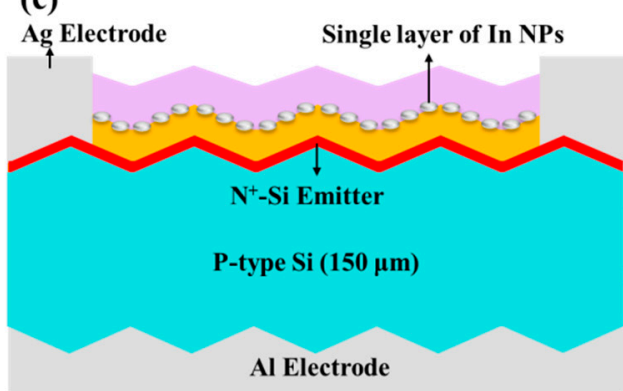

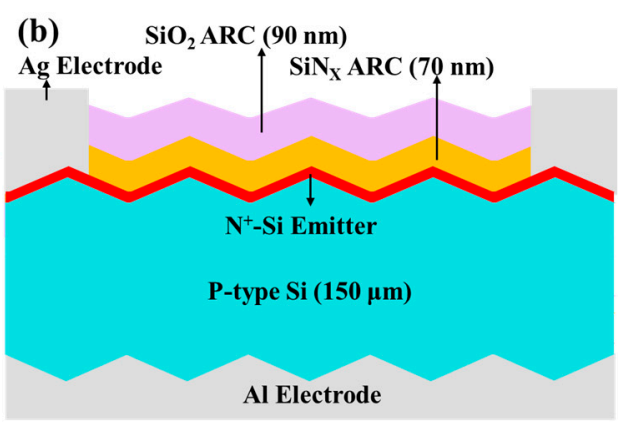

(d)

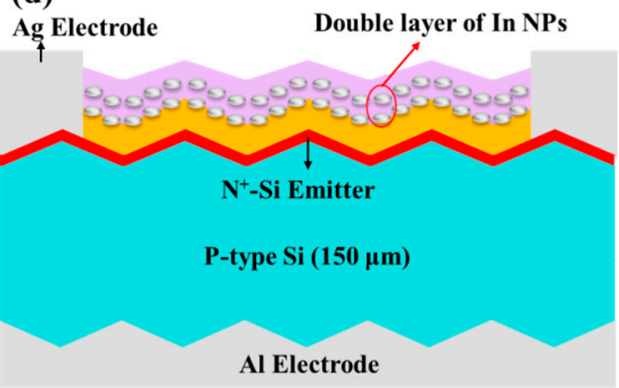

Figure 2. Schematic illustrations showing cells evaluated in this study: (a) reference textured silicon solar cell; (b) reference cell with $\mathrm{SiO}_{2}$ coating $(90 \mathrm{~nm})$; (c) reference cell with $\mathrm{SiO}_{2}$ coating $(90 \mathrm{~nm})$ embedded with single layer of In NPs; and (d) reference cell with $\mathrm{SiO}_{2}$ coating $(90 \mathrm{~nm})$ embedded with double layer of In NPs.

\subsection{EQE and Photovoltaic Performance of Plasmonic Textured Silicon Solar Cells under Incident Light of Various Angles}

We evaluated the textured silicon solar cells with and without In NP layers in terms of EQE response and photovoltaic I-V curves under illumination by an incident light source of various angles $(\theta)$, ranging from $0^{\circ}$ to $75^{\circ}$, as shown in Figure 3. The light source was fixed above a stage that could be rotated from $0^{\circ}$ to $90^{\circ}$. The light source was calibrated using an NREL-certified crystalline silicon reference cell at $0^{\circ}$ prior to measurement. The output power of the cells was calculated at each incident angle to compare the total output power under daylight illumination (from AM 0700 to PM 1700). The incident angles were meant to simulate illumination at various times, as follows: $0^{\circ}$ (noon), $45^{\circ}$ (AM 0900/PM 1500), and 75 (AM 0700/PM 1700).

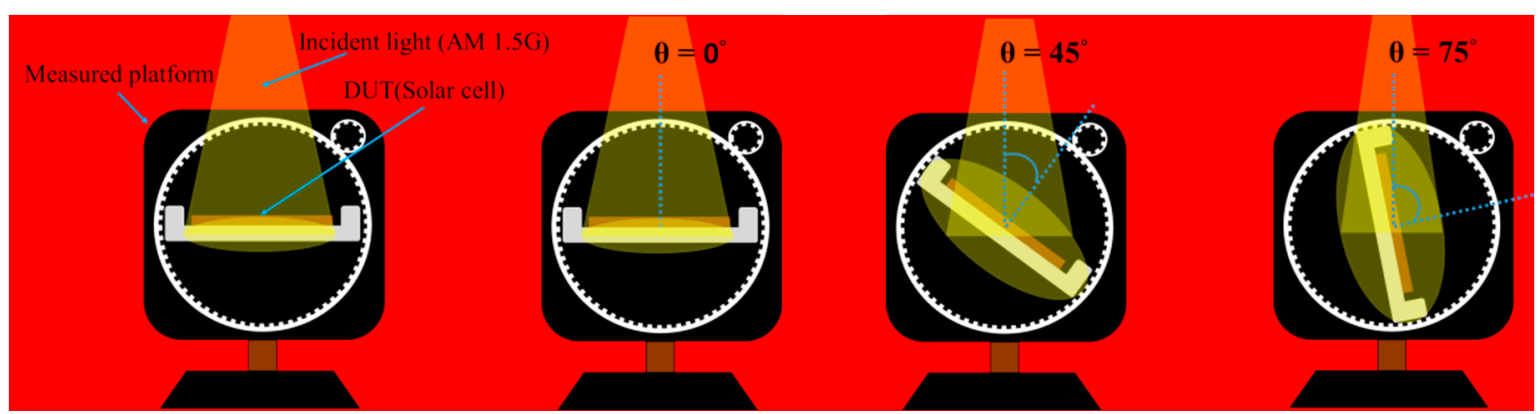

Figure 3. Varying incident light source angle $(\theta)$ while illuminating textured silicon solar.

\section{Results and Discussion}

Figure 4a presents the Raman spectra of samples with the following configurations: (1) quartz substrate $/ \mathrm{SiO}_{2}$ layer; (2) quartz substrate $/ \mathrm{SiO}_{2}$ coating embedded with single layers of In NPs of various sizes ( $3.8 \mathrm{~nm}, 5 \mathrm{~nm}$, and $7 \mathrm{~nm}$ ); and (3) quartz substrate $/ \mathrm{SiO}_{2}$ coating embedded with double 
layers of In NPs of various sizes $(3.8 \mathrm{~nm}, 5 \mathrm{~nm}$, and $7 \mathrm{~nm})$. Compared to the sample with a quartz substrate $/ \mathrm{SiO}_{2}$ coating, the samples with In NPs presented shifts in the Raman peaks at 1181, 1362, and $1485 \mathrm{~cm}^{-1}$. Generally, peaks in the Raman signal from metallic nanoparticles are an indication of SPR under a light source of specific wavelengths. We also observed an increase in the intensity of the Raman signals with an increase in the particle size and the number of NP layers. Thus, the most pronounced plasmonic effects were observed in the samples with a double layer of In NPs of $7 \mathrm{~nm}$. Figure $4 \mathrm{~b}$ presents the absorption spectra of samples with the following configurations: (1) quartz substrate $/ \mathrm{SiO}_{2}$ coating; (2) quartz substrate $/ \mathrm{SiO}_{2}$ coating embedded with single layers of In NPs of various sizes ( $3.8 \mathrm{~nm}, 5 \mathrm{~nm}$, and $7 \mathrm{~nm}$ ); and (3) quartz substrate $/ \mathrm{SiO}_{2}$ coating embedded with double layers of In NPs of various sizes $(3.8 \mathrm{~nm}, 5 \mathrm{~nm}$, and $7 \mathrm{~nm})$. The fact that the peak absorption occurred at approximately $200 \mathrm{~nm}$ indicates that the principal absorption of incident light occurred in the quartz substrate due to the bandgap of the quartz substrate (approximately $6 \mathrm{eV}$ ). Compared to the quartz substrate $/ \mathrm{SiO}_{2}$ coating sample, the sample with a single layer of In NPs presented a higher absorption band between 220 and $300 \mathrm{~nm}$, with peak absorption at approximately $260 \mathrm{~nm}$. The samples with a double layer of In NPs presented far higher absorption values due to the higher density of the indium nanoparticles and the effects of light coupling between the two nanoparticle layers.
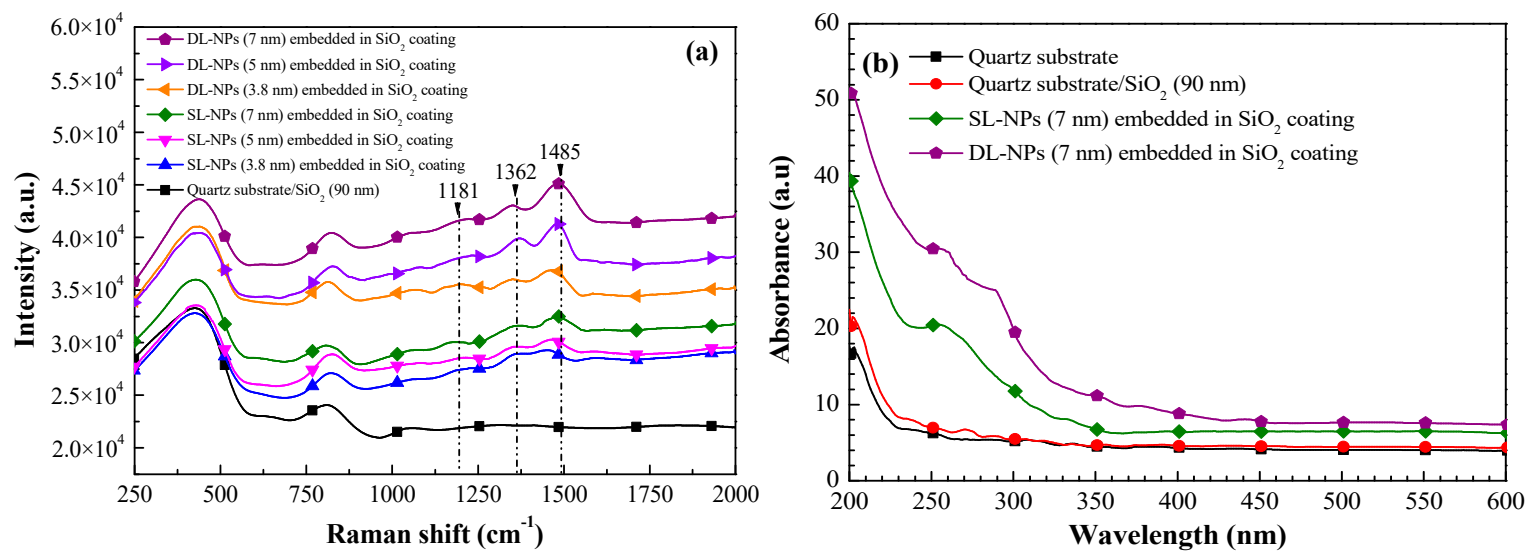

Figure 4. (a) Raman spectra; (b) absorption spectra of all tested samples.

Figure 5a,b present top-view SEM images of textured silicon solar cells without and with In NPs, respectively. These images show that the minimum and maximum spacing between pyramids on the textured surface was $4 \mu \mathrm{m}$ and $8 \mu \mathrm{m}$, respectively. The minimum and maximum heights were 4 and $7 \mu \mathrm{m}$, respectively. Figure 5c presents a particle profile of In NPs $(7 \mathrm{~nm})$ within the textured surface. This profile was generated from the inset of Figure $5 \mathrm{~b}$. The size distribution and coverage were calculated using Image-J software (National Institutes of Health, Bethesda, MD, USA). Figure 5d presents a side-view SEM image of a sample with a double layer of In NPs $(7 \mathrm{~nm})$ embedded within the $\mathrm{SiO}_{2}$ coating on a GaAs substrate. The GaAs substrate was used to examine the layer(s) of indium nanoparticles embedded in the $\mathrm{SiO}_{2}$ coating due to the ease with which it can be cleaved to a strip-bar for side-view SEM examination. In this 2D profile, it is easy to differentiate the first and second layers of indium nanoparticles within the $\mathrm{SiO}_{2}$ coating. 

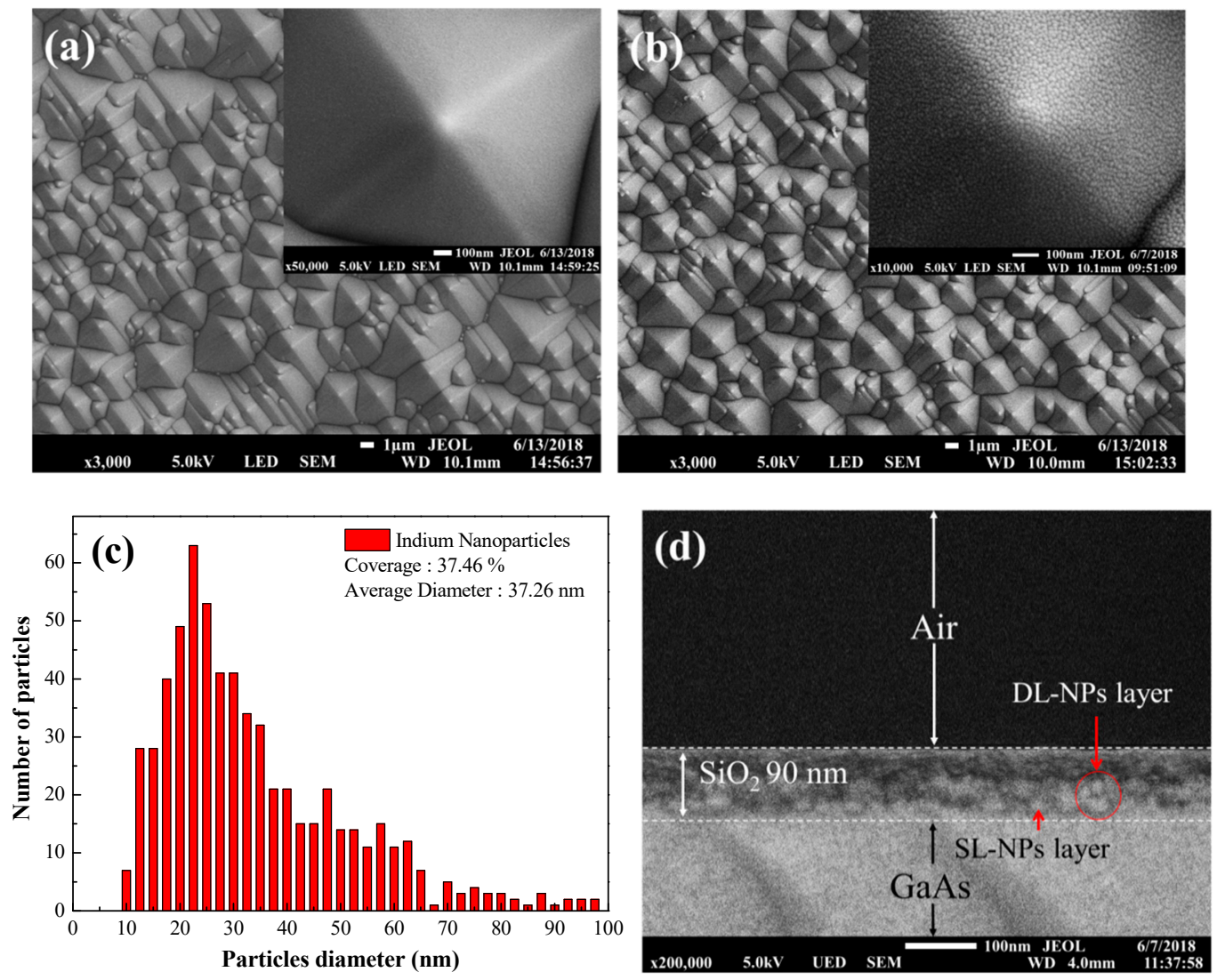

Figure 5. Top-view SEM images of textured silicon solar cells: (a) without and (b) with In NPs; (c) particle profile of In NPs (7 nm) within textured surface; (d) side-view SEM image of double layer of In NPs $(7 \mathrm{~nm})$ embedded within $\mathrm{SiO}_{2}$ coating on GaAs substrate. The inset in Figure $5 a, b$ is an enlarge graph of a pyramid structure on the cells without and with In NPs, respectively.

Figure 6a presents the optical reflectance of the reference textured silicon solar cell (Ref. Cell), the cell with an $\mathrm{SiO}_{2}$ coating without In NPs (ARC Cell), and cells with an $\mathrm{SiO}_{2}$ coating embedded with a single layer of indium nanoparticles of 3.8, 5 and $7 \mathrm{~nm}$ (SL-NPs Cell). The average weighted reference $\left(R_{\mathrm{W}}\right)$ was calculated from the wavelength range of $380-1000 \mathrm{~nm}$, as listed in Table 1. For the sake of clarity, we calculated the $R_{\mathrm{W}}$ of the cells as follows:

$$
R_{\mathrm{W}}=\frac{\int_{380 \mathrm{~nm}}^{1000 \mathrm{~nm}} R(\lambda) \varphi_{\mathrm{ph}}(\lambda) d \lambda}{\int_{380 \mathrm{~nm}}^{1000 \mathrm{~nm}} \varphi_{\mathrm{ph}}(\lambda) d \lambda} \times 100 \%
$$

where $R(\lambda)$ is the optical reflectance at a given wavelength $(\lambda)$ and $\varphi_{\mathrm{ph}}(\lambda)$ is the photon flux of AM 1.5 $\mathrm{G}$ at that wavelength $(\lambda)$. The $R_{\mathrm{W}}$ of the cells with In NPs was lower than that of the reference cell due to SPR absorption in the wavelength range of 200-350 nm (Figure $4 \mathrm{~b}$ ) and plasmonic forward scattering beyond $600 \mathrm{~nm}$, both of which were induced by the In NPs. The low $R_{\mathrm{W}}$ indicates that the NPs enabled more of the incident light to be trapped in the silicon. Samples with larger nanoparticles $(7 \mathrm{~nm})$ presented lower $R_{\mathrm{W}}$ values (3.34\%) than the samples with 3.8-nm nanoparticles (3.78\%). Again, we can see that larger In NPs were able to trap more of the incident light. We therefore fabricated samples with two layers of larger In NPs $(7 \mathrm{~nm})$ for further study and comparison. Figure $6 \mathrm{~b}$ presents the optical reflectance of the reference cell, the cell with an $\mathrm{SiO}_{2}$ coating (no NPs), and cells with single and double layers of In NPs of $7 \mathrm{~nm}$ (DL-NPs Cell). We calculated the $R_{W}$ of all tested cells over a wavelength range of 380-1000 $\mathrm{nm}$, the results of which are listed in Table 1 . The lowest $R_{\mathrm{W}}$ value $(2.32 \%)$ was obtained from the cell with the double layer of In NPs embedded within the $\mathrm{SiO}_{2}$ coating. 

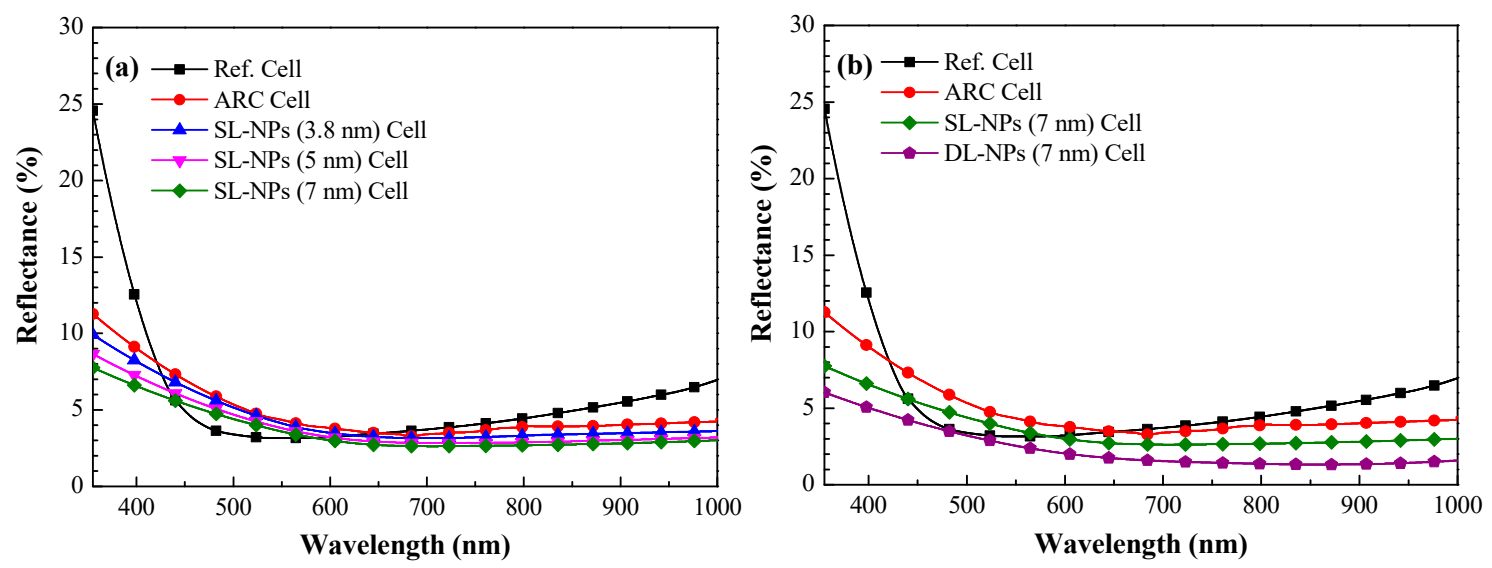

Figure 6. Optical reflectance: (a) reference cell, cell with $\mathrm{SiO}_{2}$ coating (no In NPs), cell with single layer of In NPs (3.8 nm, $5 \mathrm{~nm}$, and $7 \mathrm{~nm}$ ) embedded in $\mathrm{SiO}_{2}$ coating; (b) cell with double layer of In NPs $(7 \mathrm{~nm})$ embedded in $\mathrm{SiO}_{2}$ coating.

Table 1. Average Weighted Reference $\left(R_{W}\right)$ and Average Weighted External Quantum Efficiency $\left(E Q E_{\mathrm{W}}\right)$ of Proposed Cells.

\begin{tabular}{ccc}
\hline Silicon Solar Cell & $\begin{array}{c}\boldsymbol{R}_{\mathbf{W}} \mathbf{( \% )} \\
\text { @ 380-1000 } \mathbf{~ n m ~}\end{array}$ & $\begin{array}{c}E Q E_{\mathbf{W}} \mathbf{( \% )} \\
\text { @ 380-1000 } \mathbf{~ n m}\end{array}$ \\
\hline Ref. Cell & 4.58 & 88.82 \\
DL-ARC & 4.15 & 89.87 \\
SL-In NPs (3.8 nm) Cell & 3.78 & 90.13 \\
SL-In NPs (5 nm) Cell & 3.54 & 90.45 \\
SL-In NPs (7 nm) Cell & 3.34 & 91.35 \\
DL-In NPs (7 nm) Cell & 2.32 & 92.74 \\
\hline
\end{tabular}

Figure 7a presents the EQE response of the reference solar cell, the cell with an $\mathrm{SiO}_{2}$ coating (no In NPs), and cells with a single layer of In NPs of various sizes $\left(3.8,5\right.$, and $7 \mathrm{~nm}$ ) embedded in an $\mathrm{SiO}_{2}$ coating. The EQE values of cells with In NPs were higher than those without In NPs across the entire wavelength range, due to the effects of plasmonic forward scattering induced by the NPs. The EQE values of cells with larger NPs were slightly higher than those with smaller NPs. The EQE response values are in good agreement with the optical reflectance results. Figure $7 \mathrm{~b}$ presents the EQE response of the reference cell, the cell with a $\mathrm{SiO}_{2}$ coating (no In NPs), and cells with either a single layer of In NPs $(7 \mathrm{~nm})$ or a double layer of In NPs $(7 \mathrm{~nm})$. For the sake of clarity, we calculated the average weighted $\mathrm{EQE}\left(E Q E_{\mathrm{W}}\right)$ of the cells as follows:

$$
E Q E_{\mathrm{W}}=\frac{\int_{380 \mathrm{~nm}}^{1000 \mathrm{~nm}} E Q E(\lambda) \varphi_{\mathrm{ph}}(\lambda) d \lambda}{\int_{380 \mathrm{~nm}}^{1000 \mathrm{~nm}} \varphi_{\mathrm{ph}}(\lambda) d \lambda} \times 100 \%
$$

where $E Q E(\lambda)$ is the $E Q E$ at a given wavelength $(\lambda)$ and $\varphi_{\mathrm{ph}}(\lambda)$ is the photon flux of AM $1.5 \mathrm{G}$ at that wavelength $(\lambda)$. The $E Q E_{\mathrm{W}}$ values were as follows: double layer of 7-nm In NPs $(92.74 \%)$, single layer of 7-nm In NPs (91.35\%), $\mathrm{SiO}_{2}$ coating without NPs (88.97\%), and reference cell (88.82\%). Table 1 summarizes the $E Q E_{\mathrm{W}}$ of the cells calculated over a wavelength range of 380-1000 nm. The EQE values of cells with double layers of In NPs exceeded those of cells with a single layer due to the higher density of NPs and more pronounced plasmonic forward scattering. 

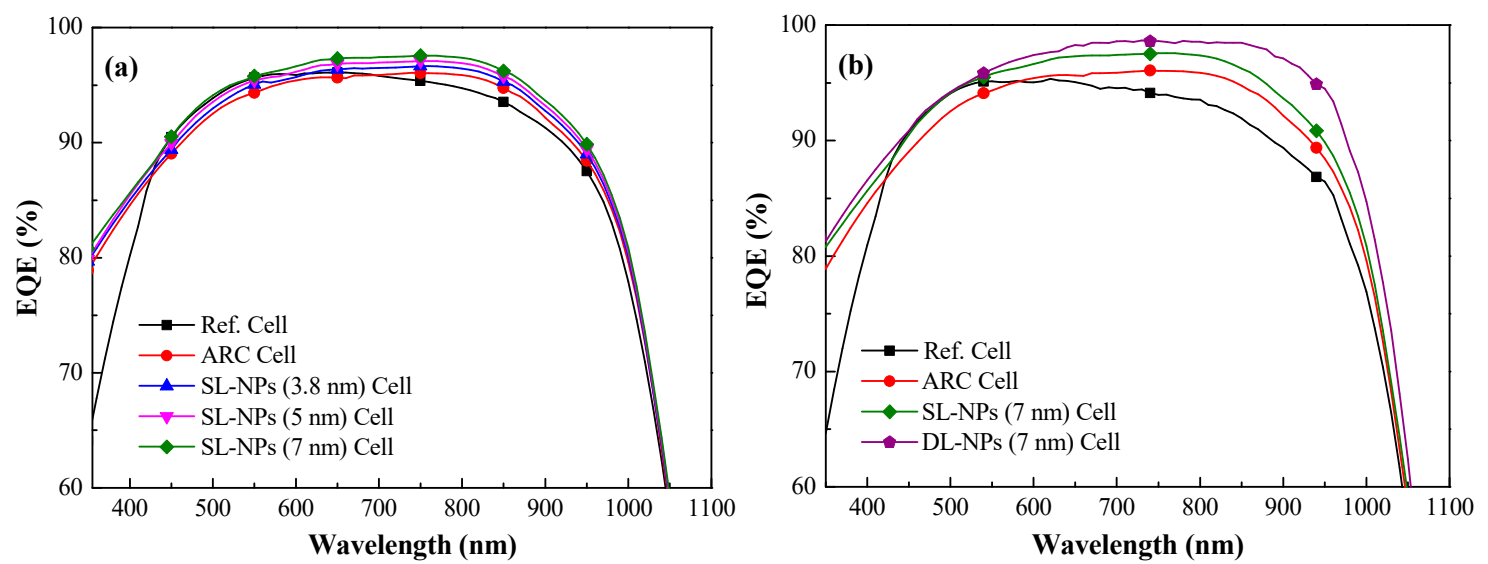

Figure 7. EQE response values: (a) reference cell, cell with $\mathrm{SiO}_{2}$ coating (no NPs), and cell with single layer of In NPs (3.8 nm, $5 \mathrm{~nm}$, and $7 \mathrm{~nm}$ ); (b) reference cell, cell with $\mathrm{SiO}_{2}$ coating (no NPs), cell with single layer of In NPs $(7 \mathrm{~nm})$, and cell with double layer of In NPs $(7 \mathrm{~nm})$.

Figure 8a presents the photovoltaic J-V curves obtained from the reference cell, the cell with an $\mathrm{SiO}_{2}$ coating (no In NPs), and cells with a single layer of In NPs of various sizes $(3.8,5$, and $7 \mathrm{~nm})$ under normal incident illumination $\left(\theta=0^{\circ}\right)$. The short-circuit current densities $\left(J_{\mathrm{sc}}\right)$ and conversion efficiency $(\eta)$ values were as follows: single layer of $7-\mathrm{nm} \mathrm{NPs}\left(40.26 \mathrm{~mA} / \mathrm{cm}^{2}\right.$ and $\left.16.61 \%\right)$, single layer of 5-nm NPs (39.95 mA/ $\mathrm{cm}^{2}$ and 16.51\%), single layer of 3.8-nm NPs $\left(39.77 \mathrm{~mA} / \mathrm{cm}^{2}\right.$ and $\left.16.44 \%\right)$, $\mathrm{SiO}_{2}$ coating without NPs (39.61 mA/ $\mathrm{cm}^{2}$ and $\left.16.34 \%\right)$, and reference cell $\left(39.19 \mathrm{~mA} / \mathrm{cm}^{2}\right.$ and $\left.16.16 \%\right)$. The $J_{\mathrm{sc}}$ values of cells with NPs were higher due to plasmonic forward scattering than those without NPs. The $J_{\mathrm{sc}}$ values of cells with larger NPs were slightly higher than those of cells with smaller NPs, due to stronger plasmonic forward scattering.
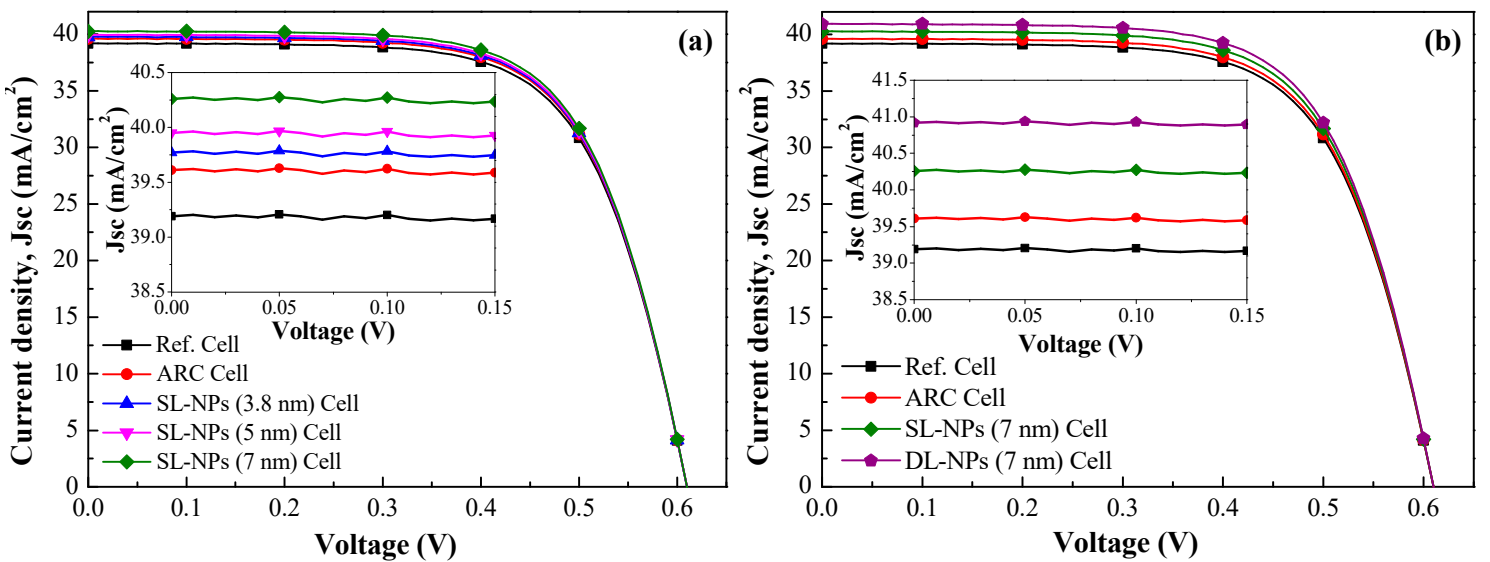

Figure 8. Photovoltaic I-V curves: (a) reference cell, cell with $\mathrm{SiO}_{2}$ coating (no NPs), and cell with single layer of In NPs ( $3.8 \mathrm{~nm}, 5 \mathrm{~nm}$, and $7 \mathrm{~nm}$ ); (b) reference cell, cell with $\mathrm{SiO}_{2}$ coating (no NPs), and cell with double layer of In NPs $(7 \mathrm{~nm})$. The inset in Figure $8 \mathrm{a}, \mathrm{b}$ is an enlarge graph of $J_{\mathrm{sc}}$ of all evaluated cells at voltage $0-0.15 \mathrm{~V}$.

Figure $8 \mathrm{~b}$ presents the photovoltaic J-V curves of cells with a single layer of 7-nm In NPs and a double layer of 7-nm In NPs. The photovoltaic performance of the proposed cells is summarized in Table 2. Adding the second layer of In NPs increased the $J_{\mathrm{sc}}$ value from 40.26 to $40.92 \mathrm{~mA} / \mathrm{cm}^{2}$, and the $\eta$ value from $16.61 \%$ to $16.97 \%$, compared to a single layer of In NPs $(7 \mathrm{~nm})$. Adding two layers of In NPs $(7 \mathrm{~nm})$ increased the $J_{\mathrm{sc}}$ value from 39.61 to $40.92 \mathrm{~mA} / \mathrm{cm}^{2}$, and the $\eta$ value from $16.34 \%$ to $16.97 \%$, compared to DL-ARC without In NPs. These results demonstrate that using larger In NPs and including multiple layers of In NPs facilitates the trapping of incident light and enhances $J_{\mathrm{sc}}$ and $\eta$, due to stronger plasmonic forward scattering. 
Table 2. Photovoltaic Performance of Proposed Cells Under AM 1.5 G Illumination at Normal Incidence.

\begin{tabular}{ccccccc}
\hline Silicon Solar Cell & $J_{\mathbf{s c}}\left(\mathbf{m A} / \mathbf{c m}^{\mathbf{2}}\right)$ & $\boldsymbol{V}_{\mathbf{o c}}(\mathbf{m V})$ & Fill Factor (\%) & $\eta(\mathbf{\%})$ & $\boldsymbol{\Delta} \boldsymbol{J}_{\mathbf{s c}} \mathbf{( \% )}$ & $\boldsymbol{\Delta} \boldsymbol{\eta}(\mathbf{\%})$ \\
\hline Ref. Cell & 39.19 & 609.40 & 67.68 & 16.16 & - & - \\
ARC Cell & 39.61 & 609.50 & 67.70 & 16.34 & 1.07 & 1.11 \\
SL-In NPs (3.8 nm) Cell & 39.77 & 609.51 & 67.85 & 16.44 & 1.47 & 1.73 \\
SL-In NPs (5 nm) Cell & 39.95 & 609.52 & 67.84 & 16.51 & 1.93 & 2.16 \\
SL-In NPs (7 nm) Cell & 40.26 & 609.53 & 67.72 & 16.61 & 2.73 & 2.78 \\
DL-In NPs (7 nm) Cell & 40.92 & 609.50 & 68.05 & 16.97 & 4.41 & 5.01 \\
\hline
\end{tabular}

Figure 9 presents the $E Q E_{\mathrm{W}}$ and $J_{\mathrm{sc}}$ of the reference cell, the cell with an $\mathrm{SiO}_{2}$ coating (no NPs), and cells with single and double layers of In NPs under incident angles of $0^{\circ}-75^{\circ}$. Increasing the incident angle resulted in a gradual decrease in $E Q E_{\mathrm{W}}$ and $J_{\mathrm{sc}}$ values in all tested cells. Compared to cells without NPs, we obtained higher $E Q E_{\mathrm{W}}$ and $J_{\mathrm{sc}}$ values from cells with single and double layers of In NPs at all incident angles. At a high incident angle of $75^{\circ}$, the double layer cells presented a $J_{\mathrm{sc}}$ decrement of $25.2 \%$ (from 40.92 to $30.06 \mathrm{~mA} / \mathrm{cm}^{2}$ ), compared to the decrement of $76.3 \%$ (from 39.61 to $9.38 \mathrm{~mA} / \mathrm{cm}^{2}$ ) from cells without NPs. Overall, $J_{\mathrm{sc}}$ was proportional to EQE and $\eta$ was proportional to $J_{\mathrm{sc}}$ in all of the photovoltaic devices. This means that a higher $J_{\mathrm{sc}}$ would no doubt result in a higher electrical output, as well as a higher conversion efficiency.
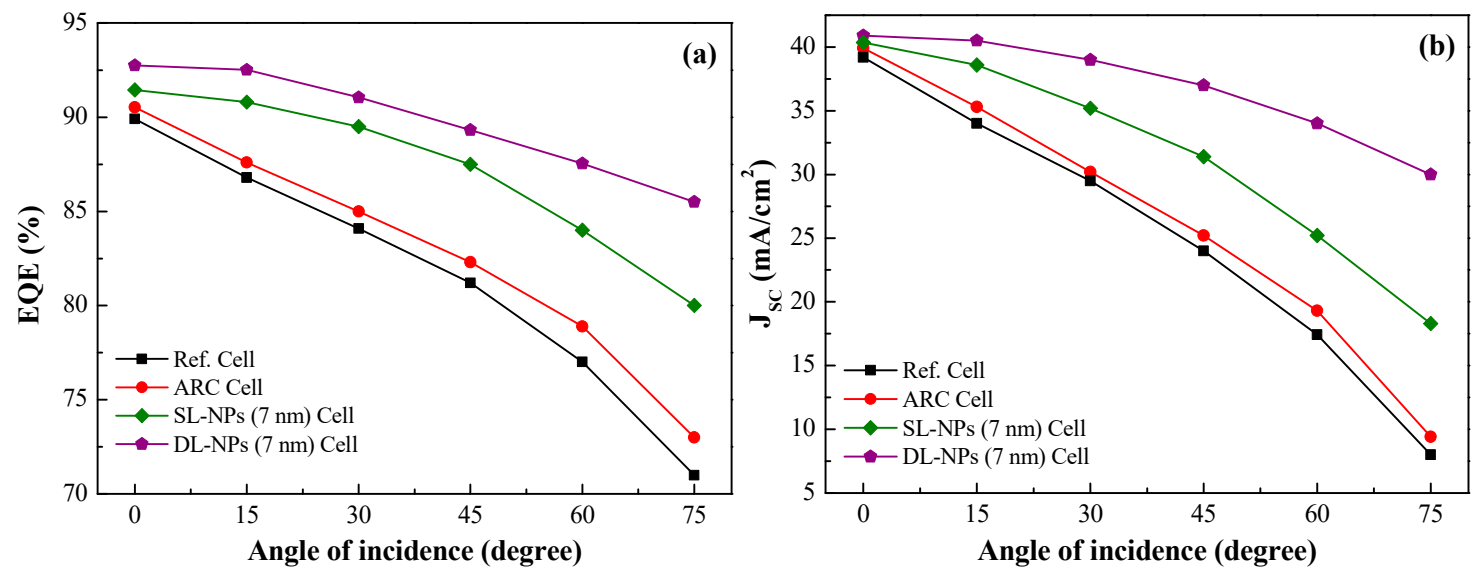

Figure 9. (a) EQE and (b) $J_{\mathrm{sc}}$ as a function of incident angle of reference cell, cell with $\mathrm{SiO}_{2}$ coating (no NPs), cell with single layer of In NPs (7 nm), and cell with double layer of In NPs $(7 \mathrm{~nm})$.

Figure 10a presents the calculated electrical output power of all evaluated solar cells under illumination from $-75^{\circ}$ to $0^{\circ}$ (sun rising; i.e., $\mathrm{AM} 0700$ to noon) and then from $0^{\circ}$ to $75^{\circ}$ (sun descending; i.e., noon to PM 1700). At all illumination times/angles, the output power of cells with a double layer of In NPs exceeded that of cells with a single layer and cells without NPs. Figure 10b presents the daily output energy of all evaluated solar cells. For the sake of clarity, we calculated the electrical output power $\left(P_{\mathrm{E}}\right)$ and the daily output energy $\left(E_{\text {day }}\right)$ of the cells as follows:

$$
P_{\mathrm{E}}=V_{\mathrm{oc}} \times J_{\mathrm{sc}} \times F F
$$

where $V_{\mathrm{oc}}$ is the open-circuit voltage, $J_{\mathrm{sc}}$ is the short-circuit current density, and $F F$ is the fill factor. The total $P_{\mathrm{E}}$ values of cells with an area of $10 \mathrm{~mm}^{2}$ were as follows: double layer of $7-\mathrm{nm}$ NPs $(141.38 \mathrm{~mW})$, single layer of 7-nm NPs $(114.13 \mathrm{~mW}), \mathrm{SiO}_{2}$ coating $(94.92 \mathrm{~mW})$, and reference cell (92.15 mW).

$$
E_{\text {day }}=\sum_{i=A M 0700}^{i=P M 1700}\left(P_{\mathrm{E}}\right)_{i} \times 1 \text { hour }
$$


the $E_{\text {day }}$ values of the cell with an $\mathrm{SiO}_{2}$ coating and the reference cell were 94.92 and $92.15 \mathrm{~mW} \cdot \mathrm{h}$, respectively. Using these as reference values, the inclusion of a single layer of In NPs (7 nm) increased $E_{\text {day }}$ by $20.24 \%$ and $23.85 \%$, respectively. The inclusion of a double layer of In NPs $(7 \mathrm{~nm})$ increased $E_{\text {day }}$ by $48.95 \%$ and $53.42 \%$, respectively.
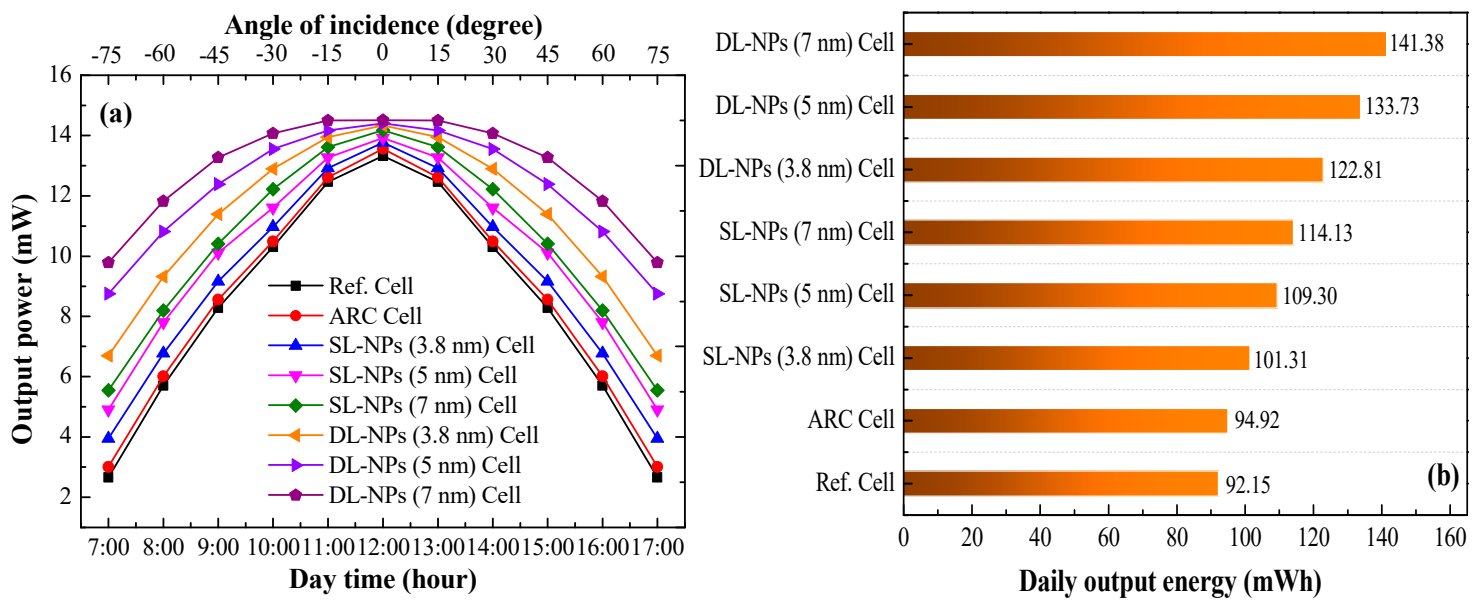

Figure 10. (a) Output electrical power; (b) output electrical energy of all tested solar cells under illumination at incidence angles from $-75^{\circ}$ to $0^{\circ}$ (sun rising) and from $0^{\circ}$ to $75^{\circ}$ (sun descending).

\section{Conclusions}

In this study, we examined the light trapping effects of In NPs according to optical reflectance and EQE measurements, with a particular focus on the dimensions of the NPs and the number of layers of NPs. A double layer of In NPs within the antireflective coating resulted in pronounced plasmonic forward scattering, which greatly enhanced the output power and conversion efficiency of the textured silicon solar cells. The inclusion of a double layer of In NPs increased the conversion efficiency from $16.16 \%$ to $16.97 \%$, compared to the reference cell without In NPs. We also examined the light-trapping performance of cells with and without In NPs at incidence angles from $0^{\circ}$ to $75^{\circ}$. At all angles, the output power delivered from cells with a double layer of In NPs exceeded that of cells with a single layer and those without NPs. The cumulative output power (one day) delivered by the cell with an area of $10 \mathrm{~mm}^{2}$ with a double layer of In NPs was $141.38 \mathrm{~mW}$, which greatly exceeds the $94.92 \mathrm{~mW}$ of the cell without In NPs.

Author Contributions: All of the authors conceived the experiments; W.-J.H. designed, analyzed, and wrote the first draft of the paper; J.-J.L. and Y.-C.Y. performed the experiments; C.-H.H. conducted EQE measurements; all authors contributed to the discussion.

Funding: The Ministry of Science and Technology of the Republic of China under Grant MOST 106-2221-E-027-101-MY3.

Acknowledgments: The authors thank Professor Ching-Fuh Lin at National Taiwan University for his support in obtaining EQE measurements.

Conflicts of Interest: The authors declare no conflict of interest.

\section{References}

1. Blakers, A.; Zin, N.; McIntosh, K.R.; Fong, K. High efficiency silicon solar cells. Energy Procedia 2013, 33, 1-10. [CrossRef]

2. Cho, C.; Oh, J.; Lee, B.; Kim, B. Combined effects of pyramid-like structures and antireflection coating on Si solar cell efficiency. J. Nanosci. Nanotechnol. 2015, 15, 7624-7631. [CrossRef] [PubMed]

3. Young, K.; Wen, Q.; Hanany, S.; Imada, H.; Koch, J.; Matsumura, T.; Suttmann, O.; Schütz, V. Broadband millimeter-wave anti-reflection coatings on silicon using pyramidal sub-wavelength structures. J. Appl. Phys. 2017, 121, 213103-1-213103-10. [CrossRef] 
4. Al-Husseini, A.M.; Lahlouh, B. Silicon pyramid structure as a reflectivity reduction mechanism. J. Appl. Sci. 2017, 17, 374-383. [CrossRef]

5. Baker-Finch, S.C.; McIntosh, K.R. Reflection of normally incident light from silicon solar cells with pyramidal texture. Prog. Photovolt Res. Appl. 2011, 19, 406-416. [CrossRef]

6. Chiao, S.C.; Zhou, J.L.; Macleod, H.A. Optimized design of an antireflection coating for textured silicon solar cells. Appl. Opt. 1993, 32, 5557-5560. [CrossRef]

7. Bouhafs, D.; Moussi, A.; Chikouche, A.; Ruiz, J.M. Design and simulation of antireflection coating systems for optoelectronic devices: Application to silicon solar cells. Sol. Energy Mater. Sol. Cells 1998, 52, 79-93. [CrossRef]

8. Ali, K.; Khan, S.A.; Mat Jafri, M.Z. Effect of double layer $\left(\mathrm{SiO}_{2} / \mathrm{TiO}_{2}\right)$ anti-reflective coating on silicon solar cells. Int. J. Electrochem. Sci. 2014, 9, 7865-7874.

9. Sanz, J.M.; Ortiz, D.; Alcaraz de la Osa, R.; Saiz, J.M.; González, F.; Brown, A.S.; Losurdo, M.; Everitt, H.O.; Moreno, F. UV plasmonic behavior of various metal nanoparticles in the near- and far-field regimes: Geometry and substrate effects. J. Phys. Chem. C 2013, 117, 19606-19615. [CrossRef]

10. Deka, N.; Islam, M.; Sarswat, P.K.; Kumar, G. Enhancing solar cell efficiency with plasmonic behavior of double metal nanoparticle system. Vacuum 2018, 152, 285-290. [CrossRef]

11. Kelly, K.L.; Coronado, E.; Zhao, L.L.; Schatz, G.C. The optical properties of metal nanoparticles: The influence of size, shape, and dielectric environment. J. Phys. Chem. B 2003, 107, 668-677. [CrossRef]

12. Tsai, F.J.; Wang, J.Y.; Huang, J.J.; Kiang, Y.W.; Yang, C.C. Absorption enhancement of an amorphous Si solar cell through surface plasmon-induced scattering with metal nanoparticles. Opt. Express 2010, 18, A207-A220. [CrossRef] [PubMed]

13. Lee, K.C.; Lin, S.J.; Lin, C.H.; Tsai, C.S.; Lu, Y.J. Size effect of Ag nanoparticles on surface plasmon resonance. Surf. Coat. Technol. 2008, 202, 5339-5342. [CrossRef]

14. Tan, H.; Santbergen, R.; Smets, A.H.M.; Zeman, M. Plasmonic light trapping in thin-film silicon solar cells with improved self-assembled silver nanoparticles. Nano Lett. 2012, 12, 4070-4076. [CrossRef] [PubMed]

15. Pillai, S.; Catchpole, K.R.; Trupke, T.; Green, M.A. Surface plasmon enhanced silicon solar cells. J. Appl. Phys. 2007, 101, 093105. [CrossRef]

16. Winans, J.D.; Hungerford, C.; Shome, K.; Rothberg, L.J.; Fauchet, P.M. Plasmonic effects in ultrathin amorphous silicon solar cells: Performance improvements with Ag nanoparticles on the front, the back, and both. Opt. Express 2015, 23, A92-A105. [CrossRef] [PubMed]

17. Sardana, S.K.; Chava, V.S.N.; Thouti, E.; Chander, N.; Kumar, S.; Reddy, S.R.; Komarala, V.K. Influence of surface plasmon resonances of silver nanoparticles on optical and electrical properties of textured silicon solar cell. Appl. Phys. Lett. 2014, 104, 073903. [CrossRef]

18. Wang, P.H.; Millard, M.; Brolo, A.G. Optimizing plasmonic silicon photovoltaics with Ag and Au nanoparticle mixtures. J. Phys. Chem. C 2014, 118, 5889-5895. [CrossRef]

19. Yu, P.; Blondeau, J.P.; Andreazza, C.; Ntsoenzok, E.; Roussel, J.; Dutheil, P.; Thomann, A.L.; Caillard, A.; Mustapha, E.; Meot, J. Influence of gold nanoparticles (Au NPs) for performance improvement of a-Si:H photovoltaic cells. Plasmonics 2015, 10, 691-701. [CrossRef]

20. Lim, S.H.; Mar, W.; Matheu, P.; Derkacs, D.; Yu, E.T. Photocurrent spectroscopy of optical absorption enhancement in silicon photodiodes via scattering from surface plasmon polaritons in gold nanoparticles. J. Appl. Phys. 2007, 101, 104309. [CrossRef]

21. Temple, T.L.; Bagnall, D.M. Optical properties of gold and aluminium nanoparticles for silicon solar cell applications. J. Appl. Phys. 2011, 109, 084343-1-084343-13. [CrossRef]

22. Parashar, P.K.; Sharma, R.P.; Komarala, V.K. Plasmonic silicon solar cell comprised of aluminum nanoparticles: Effect of nanoparticles' self-limiting native oxide shell on optical and electrical properties. J. Appl. Phys. 2016, 120, 143104. [CrossRef]

23. Parashar, P.K.; Sharma, R.P.; Komarala, V.K. Mediating broad band light trapping in silicon solar cell by aluminum nanoparticles with native oxide shell. Mater. Today Proc. 2017, 4, 12708-12715. [CrossRef]

24. Zhang, Y.; Chen, X.; Ouyang, Z.; Lu, H.; Jia, B.; Shi, Z.; Gu, M. Improved multicrystalline Si solar cells by light trapping from $\mathrm{Al}$ nanoparticle enhanced antireflection coating. Opt. Mater. Express 2013, 3, 489-495. [CrossRef]

25. Atwater, H.A.; Polman, A. Plasmonics for improved photovoltaic devices. Nat. Mater. 2010, 9, $205-213$. [CrossRef] [PubMed] 
26. Olalla, S.S.; Manuel, J.M.; Sirazul, H.; Tiago, M.; Andreia, A.; Hugo, A.; Elvira, F.; Rodrigo, M. Colloidal-lithographed $\mathrm{TiO}_{2}$ photonic nanostructures for solar cell light trapping. J. Mater. Chem. C 2017, 5, 6852-6861. [CrossRef]

27. Magnan, F.; Gagnon, J.; Fontaine, F.G.; Boudreau, D. Indium@silica core-shell nanoparticles as plasmonic enhancers of molecular luminescence in the UV region. Chem. Commun. 2013, 49, 9299-9301. [CrossRef]

28. Das, R.; Soni, R.K. Indium nanoparticles for ultraviolet surface-enhanced Raman spectroscopy. AIP Conf. Proc. 2018, 1953, 030123. [CrossRef]

29. Haynes, C.L.; Duyne, R.P.V. Plasmon-sampled surface-enhanced Raman excitation spectroscopy. J. Phys. Chem. B 2003, 107, 7426-7433. [CrossRef]

30. Lee, Y.Y.; Ho, W.J.; Liu, J.J.; Lin, C.H. Light-trapping performance of silicon thin-film plasmonics solar cells based on indium nanoparticles and various $\mathrm{TiO}_{2}$ space layer thicknesses. Jpn. J. Appl. Phys. 2014, 53, $06 \mathrm{JE} 11$. [CrossRef]

31. Ho, W.J.; Lin, J.C.; Liu, J.J.; Yeh, C.W.; Syu, H.J.; Lin, C.F. Plasmonic light scattering in textured silicon solar cells with indium nanoparticles from normal to non-normal light incidence. Materials 2017, 10, 737. [CrossRef] [PubMed]

32. Ho, W.J.; Su, S.Y.; Lee, Y.Y.; Syu, H.J.; Lin, C.F. Performance-enhanced textured silicon solar cells based on plasmonic light scattering using silver and indium nanoparticles. Materials 2015, 25, 6668-6676. [CrossRef] [PubMed]

33. Ho, W.J.; Lee, Y.Y.; Lin, C.H.; Yeh, C.W. Performance enhancement of plasmonics silicon solar cells using $\mathrm{Al}_{2} \mathrm{O}_{3} /$ In NPs $/ \mathrm{TiO}_{2}$ antireflective surface coating. Appl. Sur. Sci. 2015, 354, 100-105. [CrossRef]

(C) 2018 by the authors. Licensee MDPI, Basel, Switzerland. This article is an open access article distributed under the terms and conditions of the Creative Commons Attribution (CC BY) license (http:// creativecommons.org/licenses/by/4.0/). 